\title{
RESEARCH PAPER \\ Improvement in nutritional quality of fibrous food via in vitro digestion by Aspergillus niger
}

\author{
Alejandro Velásquez ${ }^{1,2}$, Pierre-Guy Marnet ${ }^{3}$, and Rodrigo Arias ${ }^{4}$ \\ 'Área de Producción Animal, Escuela de Agronomía, Facultad de Recursos Naturales. ${ }^{2}$ Núcleo de \\ Investigación en Producción Alimentaria. Universidad Católica de Temuco. Rudecindo Ortega 02950. \\ Temuco, Chile. \\ ${ }^{3}$ Département Productions Animales, Agroalimentaire, Nutrition (P3AN). UMR INRA-Agrocampus Ouest \\ 1348, Rennes, France. \\ ${ }^{4}$ Instituto de Producción Animal, Universidad Austral de Chile. Independencia 641, Valdivia, Chile.
}

\begin{abstract}
A. Velásquez, P. Marnet, and R. Arias. 2015. Improvement in nutritional quality of fibrous food via in vitro digestion by Aspergillus niger. Cien. Inv. Agr. 42(1): 45-55. In a first experiment, the effect of in vitro incubation with Aspergillus niger $(A n)$ on the chemical composition of different fibrous substrates was studied. In a second experiment, the effect of incubation time ( 0,72 and $144 \mathrm{~h})$ on in vitro digestion with $A n$ of dry matter (IVDMD), neutral detergent fiber (DVNDF) and acid detergent fiber (DVADF) was evaluated for different substrates. Wheat straw, WS; barley straw, BS; oat hulls, OH; dehydrated alfalfa, DA; and dehydrated ryegrass, DB substrates were evaluated. In both experiments, incubations were performed in $250 \mathrm{~mL}$ Erlenmeyer flasks; $2 \mathrm{~g}$ of substrate was added to a culture medium (pH =6), and incubated at $28{ }^{\circ} \mathrm{C}$ with constant ventilation. The $A n$ dose consisted of $3 \mathrm{~mL}$ of a solution of $5.3 \times 10^{6}$ spores $\mathrm{mL}^{-1}$ per flask. Incubation time for the first experiment was 144 h. After incubation, the contents of the flasks were homogenized in a blender for one minute. Subsequently, bromatological analysis was conducted without separating the An biomass. No interaction effects among any studied variables were observed. An incubation effected cell wall (NDF) and lignocellulose (ADF) content. An increase in true protein (TP) and soluble nitrogen (SN) was observed for all substrates tested, but responses differed depending on the type of substrate. The largest increases in TP were observed in DA and DB substrates $(0.55$ and $0.63 \%$ DM, respectively). IVDMD, DVNDF and DVADF were affected by the type of substrate and incubation time. The highest value of IVDMD ${ }_{144}$ was observed in the DAAn treatment $(49.47 \%$ DM), followed by the DBAn treatment, with a value of $45.51 \%$ DM. OHAn showed the lowest value of $\operatorname{IVDMD}_{144}(29.38 \% \mathrm{DM})$. The results suggest that $A n$ possesses fibrolytic and metabolic potential for improving the nutritional value of fibrous foods through of the digestion of structural carbohydrates and the liberation of nitrogenous fractions embedded in cell walls, producing a change in the chemical composition and the potential digestibility of treated foods.
\end{abstract}

Key words: Aspergillus niger, fibrous substrates, in vitro digestion, nutritional quality.

\section{Introduction}

High cellulose, hemicellulose and lignin content of fibrous foods are among the major fac-

Received October 17, 2014. Accepted March 17, 2015. Corresponding author: avelasquez@uct.cl tors responsible for the low nutritional values observed in livestock feed. This is not only because of the chemical composition of fibrous foods but also because of their low digestive potential in the animal's gastrointestinal system. These foods, under a biotechnology program 
using saprophytic fungi, could be modified to improve their nutritional quality by decreasing the cell wall content via digestion, and also by increasing nutrients obtained from the biomass of the microorganism growing on the incubated substrate (Kuhad et al., 1997; Shrivastava et al., 2012). Wheat straw (WS) and barley straw (BS) are important agricultural residues in the La Araucanía region and are usually burned or discarded. Furthermore, oat hulls (OH), an agro-industrial by-product, are also generated in significant quantities in this region of Chile. These fibrous foods have the potential to be used as animal feed, preferably in ruminants. However, the nutritional value of these foods is low, even for ruminants, due to their high lignocellulosic fractions and low crude protein (CP), thus limiting their use as dietary ingredients (Nagarajan, 2005; Arora et al., 2011). Indeed, bromatological measurements on WS and $\mathrm{OH}$ performed in our laboratory yielded values of $86.9 \%$ and $76 \%$ neutral detergent fiber (NDF), $55.6 \%$ and $42 \%$ acid detergent fiber (FDA), and $4.1 \%$ and $4.6 \% \mathrm{CP}$, respectively (Velásquez and Arias, 2013). Sarkar et al. (2012), in Pensupa et al. (2013), found WS to contain 35-45\% cellulose, $20-30 \%$ hemicellulose, $8-15 \%$ lignin, $3.1 \%$ protein and $10.1 \%$ ash. The low digestibility of lignocellulosic fractions is due to lignin-covered polysaccharide microfibers, structured in a compact, crystalline, heterogeneous complex, where the lignin protects the polysaccharides against action by hydrolytic enzymes and other external factors, in addition to stabilizing the complex (Leonowicz et al., 1999; Villas-Boas et al., 2002). The high lignocellulosic content present in these agricultural residues and agroindustrial by-products inhibits the enzymatic action of the microbial community in the rumen, resulting in minimal degradation of organic matter, and consequently reduced availability of energy and nitrogen for the ruminal ecosystem (Sahoo et al., 2002; Shrivastava et al., 2012). Various techniques have been applied to improve the nutritional value of these fibrous foods, including physical, chemical and biological treat- ments (Liu et al., 1999; Tuyen et al., 2012). The biological methods include those based on the use of hydrolytic enzymes and microorganisms, particularly saprophytic fungi with fibrolytic potential (Zafar et al., 1996; Kuhad et al., 1997; Rodrigues et al., 2008; Gaitán-Hernández et al., 2011). These biological methods can improve the nutritional quality of fibrous foods by increasing true protein (TP) content (Velásquez et al., 2012), and improve digestibility by decreasing cell wall content (Kuhad et al., 1997; Villas-Boas et al., 2002). The advantage of biological methods for improving the nutritional quality of these foods over physical and chemical techniques is their low environmental impact, which generate little pollution and require little energy for their application (Basu et al., 2002; Shrivastava et al., 2012). Aspergillus niger (An) is a saprophytic fungus with potent fibrolytic activity, belonging to the phylum Ascomycota, class Ascomycetes, order Eurotiales and family Trichocomaceae. This enzymatic ability to digest cell walls, along with starches, simple sugars and proteins, make it a suitable fungus to grow on fibrous substrates (Hernández-Díaz et al., 2010; Rajesh et al., 2010). These filamentous fungi are naturally adapted for growth on plant surfaces, which they use as support for the development of aerial mycelia and reproductive structures. This close contact with the substrate stimulates secretion of the hydrolytic enzymes responsible for extracellular digestion (Jones, 1994). Among the reported hydrolytic enzymes that can be synthesized by $A n$ are cellulases, exo- $\beta-1,4$-mannosidase, endo- $\alpha$-1.5-arabinase, $\alpha$-1-arabinofuranosidase, endo-galactanase, feruloyl esterase (Park et al., 2002; Howard et al., 2003; Sánchez, 2009), glucoamylase, xylanases, endo- $\beta$-1.4-glucanase and exo- $\beta$-1.4-glucanase (Kang et al., 2004; Pensupa et al., 2013). Considering this powerful pool of fibrolytic enzymes, $A n$ could degrade most fibrous substrates, using the carbon skeletons and energy generation to fuel reproduction and growth. Consequently, the first objective of this study was to evaluate the effect of in vitro incubation of different substrates with $A n$ 
on the chemical composition of fibrous foods. The second objective was to study the effect of substrate type and incubation time on in vitro digestion of dry matter, neutral detergent fiber and acid detergent fiber by $A n$.

\section{Materials and methods}

Experiment 1: Effect of in vitro incubation with Aspergillus niger on the chemical composition of fibrous substrates

$A n$ strains (ATCC-1015) were provided by the veterinary medicine school's microbiology laboratory (Catholic University of Temuco). An strains were seeded in Petri dishes with a potato dextrose agar culture medium, then dried in a forced air oven (Arquimed WTB Binder) at $26^{\circ} \mathrm{C}$ for 4 days, and cooled and held at $4{ }^{\circ} \mathrm{C}$ until incubation. Incubations were performed in $250 \mathrm{~mL}$ Erlenmeyer flasks fitted with a glass and rubber stopper to ensure aerobic conditions during incubation (Robinson and Nigam, 2003; Velásquez and Arias, 2013). The flasks were sterilized with alcohol (98\%) and UV radiation (Laminar Flow Cabinet: Streamline SHC-4A1) for $30 \mathrm{~min}$. Two grams of substrate were added to a culture medium consisting of $8 \mathrm{~mL}$ of $50 \mathrm{mM}$ Tris buffer $(\mathrm{pH}=6), 2 \mathrm{~mL}$ of streptomycin antibiotic $(0.1 \% \mathrm{w} / \mathrm{v})$ and $2 \mathrm{~mL}$ of urea $1 \%(\mathrm{w} / \mathrm{v})$. Urea was added to ensure that nitrogen was not a limiting factor for $A n$ metabolism. The dose of $A n$ (inoculum) per flask consisted of $3 \mathrm{~mL}$ of a solution with $5.3 \times 10^{6}$ spores $\mathrm{mL}^{-1}$ (determined by hemocytometer). This dose established a substrate-limiting kinetic condition, which was determined by preliminary experiments in our laboratory. Basal input of $A n$ to the culture medium was corrected by inoculum incubation in inert material, without organic substrate (Velásquez et al., 2012). The incubation time was $144 \mathrm{~h}$ under continuous ventilation $\left(28^{\circ} \mathrm{C}\right)$. After incubation, we homogenized the total contents of the flask in a blender for one minute. Subsequently, bromatological analysis was conducted on the total mass incubated, without separating the $A n$ biomass.

\section{Collection and preparation of fibrous substrates}

Triticum aestivum (wheat straw, WS), Hordeum vulgare (barley straw, BS), Avena sativa (oat hulls, $\mathrm{OH}$ ), Medicago sativa (dehydrated alfalfa, DA) and Lollium perenne (dehydrated ryegrass, DB) were evaluated. Ten subsamples $(0.5 \mathrm{~kg})$ of each substrate were collected and were subsequently mixed. WS and BS were obtained from crop stubble randomly selected from within $\mathrm{La}$ Araucanía Region. $\mathrm{OH}$ was a by-product of the industrial processing of oats for human and animal consumption; samples were also randomly selected from La Araucanía Region agro-industries. DA and DB were cut before flowering from pastures established within the IX region (first cut), and then were processed in the laboratory. During collection, all samples were visually inspected for structural damage and contaminants; any impurities in vegetable materials were removed. In addition, substrates were checked for the presence of phytopathogenic agents by visual inspection, and also by microscopic examination in the laboratory. Similarly, $\mathrm{OH}$ was inspected for contaminating microbial agents and purity (visually and microscopically). All substrates (subsamples combined) were washed with distilled water for 20 minutes, then autoclaved in $250 \mathrm{~mL}$ flasks at $121^{\circ} \mathrm{C}$ for $15 \mathrm{~min}$, and finally dried in an oven at $60^{\circ} \mathrm{C}$ for $48 \mathrm{~h}$. Subsequently, samples were chopped (size range $0.2-0.5 \mathrm{~cm}$ ). Later, all substrates were subjected to chemical composition analysis.

\section{Chemical composition of fibrous substrates and generated biomass}

Bromatological analysis was performed on fibrous substrates (Table 1) and post-incubation biomass (experiments 1 and 2). AOAC (1990) methods were used to determine dry matter (DM, official method 934.01), ash (official method 942.05) and N (official method 984.13) content. Neutral detergent fiber (NDF) and acid detergent fiber (ADF) were determined by the method of Van 
Table 1. Chemical composition of fibrous substrates.

\begin{tabular}{cccccccccc}
\hline Substrate $^{1}$ & $\begin{array}{c}\mathrm{DM}^{2} \\
\%\end{array}$ & $\begin{array}{c}\text { Ash } \\
\% \mathrm{DM}\end{array}$ & $\begin{array}{c}\mathrm{CP} \\
\% \mathrm{DM}\end{array}$ & $\begin{array}{c}\mathrm{NDF}^{3} \\
\% \mathrm{DM}\end{array}$ & $\begin{array}{c}\mathrm{ADF} \\
\% \mathrm{DM}\end{array}$ & $\begin{array}{c}\mathrm{TP}^{4} \\
\% \mathrm{CP}\end{array}$ & $\begin{array}{c}\mathrm{SN} \\
\% \mathrm{CP}\end{array}$ & $\begin{array}{c}\mathrm{NDIN}^{5} \\
\% \mathrm{CP}\end{array}$ & $\begin{array}{c}\text { ADIN } \\
\text { CP }\end{array}$ \\
\hline WS & $96.3^{6}$ & 8.1 & 4.0 & 86.2 & 54.6 & 85.0 & 22.8 & 48.5 & 26.3 \\
BS & 96.8 & 7.5 & 4.4 & 84.7 & 55.6 & 89.4 & 24.1 & 47.2 & 25.9 \\
OH & 97.1 & 7.4 & 4.5 & 86.3 & 65.4 & 86.5 & 18.3 & 41.3 & 26.8 \\
DA & 93.5 & 11.4 & 18.3 & 41.7 & 28,3 & 89.6 & 21.2 & 23.1 & 13.4 \\
DB & 94.2 & 12.3 & 11.2 & 57.8 & 34.5 & 90.4 & 14.3 & 32.1 & 15.9 \\
\hline
\end{tabular}

${ }^{1}$ WS: wheat straw, BS: barley straw, OH: oats hull, DA: dehydrated alfalfa, DB: dehydrated ballica.

${ }^{2}$ DM: dry matter, CP: crude protein.

${ }^{3}$ NDF: neutral detergent fiber, ADF: acid detergent fiber.

${ }^{4}$ TP: true protein, $\mathrm{SN}$ : N soluble fraction.

${ }^{5}$ NDIN: insoluble $\mathrm{N}$ in neutral detergent, ADIN: insoluble $\mathrm{N}$ in acid detergent.

${ }^{6}$ Each value represents the chemical assay of three samples.

Soest et al. (1991). Fibrous fractions were determined with alpha amylase; these were expressed exclusive of residual ash. True protein (TP) was determined from buffer-insoluble $\mathrm{N}$, and the fraction of trichloroacetic acid (TCA)-insoluble $\mathrm{N}$ to buffer-soluble N. Soluble N (SN) was measured by vacuum filtration (Whatman paper $\mathrm{N}^{\circ} 41$ ) using the Kjeldahl method (AOAC, 1990). Insoluble N in neutral detergent fiber (NDIN) and insoluble $\mathrm{N}$ in acid detergent fiber (ADIN) were determined by measuring Kjeldahl $\mathrm{N}$ in the fiber residues.

Experiment 2: Effect of incubation time on the dry matter, neutral detergent fiber and acid detergent fiber digestion of different substrates digested with Aspergillus niger (An)

Using the same incubation protocol as the first experiment, a second trial measured the effect of substrate type and incubation time (0,72 and 144 h) on the dry matter (IVDMD), NDF (DVNDF) and ADF (DVADF) digestion of fibrous foods digested with An (in vitro). Preliminary experiments in our laboratory (unpublished) showed an asymptotic time of DM digestion of approximately $120 \mathrm{~h}$; however, the levels of digestion for shorter periods of time are unknown. Separate experimental setups were used for each incubation time. The inoculum dose ensured a substrate-limiting condition, sufficient to evaluate the susceptibility of the substrate to enzymatic digestion. After 72 $\mathrm{h}$ and $144 \mathrm{~h}$, the flasks were withdrawn from the stove and $10 \mathrm{~mL}$ of cold water $\left(7^{\circ} \mathrm{C}\right)$ was added to each flask to stop $A n$ enzymatic activity. The contents of the flasks were subsequently filtered using Whatman filter paper $\left(\mathrm{N}^{\circ} 41\right)$ in a vacuum funnel; mass balance was performed after bromatological analysis of the undigested residue to determine IVDMD, DVNDF and DVADF. Values from each treatment were corrected using the respective blanks, which consisted of substrates incubated without $A n$.

\section{Statistical analysis}

For both tests, the experimental design was completely randomized, with factorial arrangement, $2 \times 5$ and $5 \times 3$, for experiments 1 and 2 , respectively. For experiment 1 , the first factor corresponded to incubation with and without $A n$, and the second corresponded to the 5 types of fibrous substrates. For experiment 2, the first factor corresponded to the 5 types of substrate, and the second factor corresponded to the three incubation times $(0,72$ and $144 \mathrm{~h}$ ). The general statistical model for both experiments was $\mathrm{Y}_{\mathrm{ijk}}=\mu+\alpha_{\mathrm{i}}+\beta_{\mathrm{j}}+(\alpha \beta)_{\mathrm{ij}}+\mathrm{e}_{\mathrm{ij \textrm {k }}}$, where $\mathrm{Y}_{\mathrm{ijk}}=$ the observed value (chemical composition, IVDMD, DVNDF and DVADF); $\mu=$ the generalized mean; $\alpha_{i}=$ the effect of the $i^{\text {th }}$ level of factor $\alpha ; \beta_{\mathrm{j}}=$ the effect of the $\mathrm{j}^{\text {th }}$ level of factor $\beta ;(\alpha \beta)_{\mathrm{ij}}$ $=$ the interaction between the $i^{\text {th }}$ level of factor $\alpha$ and the $\mathrm{j}^{\text {th }}$ level of factor $\beta$; $\mathrm{e}_{\mathrm{ijk}}=$ the experimental 
error. Each experiment was repeated three times in duplicate. The normality of the data was verified using the Shapiro-Wilk procedure $(\mathrm{P}>0.05)$. Levene's statistic was used to test for homogeneity of variance $(\mathrm{P}>0.05)$. In both experiments, the experimental unit was a matrass $(250 \mathrm{~mL})$ with its respective incubation. The results were subjected to an ANOVA with a significance level of 5\%, with an analysis of interaction and main effects. Treatment means were compared using Tukey's method (5\% significance). Statistical analysis was performed with JMP® software (version 5.0.1.2, SAS Inc., Cary, NC, 2003).

\section{Results}

Experiment 1: Effect of in vitro incubation with Aspergillus niger on the chemical composition of fibrous substrates

No interaction effect was observed among any of the studied variables $(\mathrm{P}=0.28-\mathrm{P}=0.37)$. Incubation with $A n$ affected the amount of NDF $(\mathrm{P} \leq 0.001)$, $\operatorname{ADF}(\mathrm{P} \leq 0.001), \mathrm{TP}(\mathrm{P} \leq 0.01), \mathrm{SN}(\mathrm{P} \leq 0.01), \mathrm{NDIN}$ $(\mathrm{P} \leq 0.05)$ and $\mathrm{ADIN}(\mathrm{P} \leq 0.05)$. Additionally, chemical composition was affected by the type of substrate $(\mathrm{P} \leq 0.0001-\mathrm{P} \leq 0.01)$ (Table 2$)$. The greatest reduction in NDF $(\mathrm{P} \leq 0.05)$ was observed with the substrate BS $(24.68 \% \mathrm{DM})$, and the smallest reduction was observed $(\mathrm{P} \leq 0.05)$ with the substrate DA ( $15.56 \% \mathrm{DM})$. The average decrease in NDF across all substrates was $20.86 \% \mathrm{DM}$. The greatest decrease in $\mathrm{ADF}(\mathrm{P} \leq 0.05)$ was observed in $\mathrm{OH}(8.53 \% \mathrm{DM})$, and the smallest decrease was observed $(\mathrm{P} \leq 0.05)$ in DA $(4.73 \% \mathrm{DM})$. The average decrease in ADF was $6.71 \% \mathrm{DM}$ for all substrates. However, the greatest increases in $\mathrm{TP}(\mathrm{P} \leq 0.05)$ were observed in the substrates DA and DB $(0.55 \%$ and $0.63 \% \mathrm{DM}$, respectively). WS, BS and $\mathrm{OH}$ substrates showed an average increase of $0.32 \% \mathrm{DM}$ and were not different from one another $(\mathrm{P}>0.05)$. These changes suggest a possible increase in $A n$ biomass as a by-product of digestion and growth on the fibrous substrates, with a consequent increase in protein synthesis.
Furthermore, DA showed the greatest increase in solubility of nitrogenous compounds, increasing SN $12.11 \%$ CP, whereas DB showed the smallest increase in $\mathrm{SN}(6.84 \% \mathrm{CP})$. On average, across all substrates, $\mathrm{SN}$ increased by $9.69 \% \mathrm{CP}$. For N associated with cell walls (NDIN), WS showed the greatest decrease $(\mathrm{P} \leq 0.05)$, with a value of $4.57 \%$ $\mathrm{CP}$; there was no difference in NDIN among the rest of the substrates, which exhibited an average decrease of $4.04 \%$ CP. For $\mathrm{N}$ insoluble in acid detergent fiber (ADIN), BS substrate showed the greatest decrease $(\mathrm{P} \leq 0.05)$, yielding a value of $3.19 \%$ $\mathrm{CP}$. The smallest decrease in ADIN $(\mathrm{P} \leq 0.05)$ was in $\mathrm{DB}(1.46 \% \mathrm{CP})$. Although proteolytic activity of $A n$ was not measured directly in this study, the decreased the levels of NDIN and ADIN, and increased solubility of nitrogen compounds (SN), suggest some proteolytic activity by $A n$, corroborating the proteolytic potential observed in other assays developed in our laboratory, and in the laboratories of others.

Experiment 2: Effect of incubation time on the dry matter, neutral detergent fiber and acid detergent fiber digestion of different substrates digested with Aspergillus niger (An)

The results of the experiment on time of incubation and in vitro digestion of DM (IVDMD), NDF (DVNDF) and ADF (DVADF) in different substrates by $A n$ are presented in Table 3. First, the statistical analysis indicated that there was no interaction effect among any of the parameters studied $(\mathrm{P}=0.28-\mathrm{P}=0.46)$. The results revealed that IVDMD $_{72}$ and IVDMD ${ }_{144}$ were affected by the type of substrate ( $\mathrm{P} \leq 0.001$ and $\mathrm{P} \leq 0.001$, respectively). The greatest value of $\operatorname{IVDMD}_{144}(\mathrm{P} \leq 0.05)$ was observed in the treatment DAAn $(49.47 \% \mathrm{DM})$, followed by the treatment DBAn $(45.51 \% \mathrm{DM})$. IVDMD $_{144}$ did not differ between WSAn and BSAn ( $P>0.05)$, and averaged 33.77\% DM. OHAn had the lowest level $(\mathrm{P} \leq 0.05)$ of $\operatorname{IVDMD}_{144}(29.38 \%$

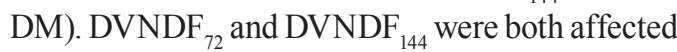
by the type of substrate $(\mathrm{P} \leq 0.001$ and $\mathrm{P} \leq 0.001)$, and there were differences between them in all 
Table 2. Effect of in vitro incubation with Aspergillus niger $(A n)$ and type of substrate on the chemical composition of fibrous foods (WS: wheat straw, BS: barley straw, OH: oats hull, DA: dehydrated alfalfa and DB: dehydrated ballica). Experiment 1 .

\begin{tabular}{|c|c|c|c|c|c|c|c|}
\hline Treatment $^{1}$ & $\begin{array}{l}\mathrm{NDF}^{2} \\
\% \mathrm{DM}\end{array}$ & $\begin{array}{c}\mathrm{ADF} \\
\% \mathrm{DM}\end{array}$ & $\begin{array}{c}\mathrm{CP}^{3} \\
\% \mathrm{DM}\end{array}$ & $\begin{array}{c}\mathrm{TP} \\
\% \mathrm{DM}\end{array}$ & $\begin{array}{c}\mathrm{SN} \\
\% \mathrm{CP}\end{array}$ & $\begin{array}{l}\mathrm{NDIN}^{4} \\
\% \mathrm{CP}\end{array}$ & $\begin{array}{l}\text { ADIN } \\
\% \text { CP }\end{array}$ \\
\hline WSAn & $61.74 b^{5}$ & $46.24 \mathrm{~b}$ & 4.12 & $3.78 \mathrm{a}$ & $32.34 \mathrm{a}$ & $43.96 \mathrm{~b}$ & $23.67 \mathrm{~b}$ \\
\hline WSs & $85.55 \mathrm{a}$ & $53.63 \mathrm{a}$ & 4.09 & $3.47 \mathrm{~b}$ & $23.01 \mathrm{~b}$ & $48.53 \mathrm{a}$ & $26.34 \mathrm{a}$ \\
\hline BSAn & $59.54 \mathrm{~b}$ & $46.94 \mathrm{~b}$ & 4.47 & $4.23 \mathrm{a}$ & $34.72 \mathrm{a}$ & $43.45 \mathrm{~b}$ & $22.85 \mathrm{~b}$ \\
\hline BSs & $84.22 \mathrm{a}$ & $54.31 \mathrm{a}$ & 4.42 & $3.91 \mathrm{~b}$ & $23.41 \mathrm{~b}$ & $47.33 \mathrm{a}$ & $26.04 \mathrm{a}$ \\
\hline OHAn & $64.32 \mathrm{~b}$ & $54.35 \mathrm{~b}$ & 4.62 & $4.24 \mathrm{a}$ & $27.89 \mathrm{a}$ & $36.12 \mathrm{~b}$ & $24.66 \mathrm{~b}$ \\
\hline OHs & 85.77 a & $62.88 \mathrm{a}$ & 4.56 & $3.92 \mathrm{~b}$ & $19.02 \mathrm{~b}$ & $40.28 \mathrm{a}$ & $26.74 \mathrm{a}$ \\
\hline DAAn & $26.77 \mathrm{~b}$ & $23.12 b$ & 18.42 & $16.86 \mathrm{a}$ & $34.56 \mathrm{a}$ & $19.81 \mathrm{~b}$ & $12.11 \mathrm{~b}$ \\
\hline DAs & $42.33 \mathrm{a}$ & $27.85 \mathrm{a}$ & 18.32 & $16.31 \mathrm{~b}$ & $22.45 \mathrm{~b}$ & 23.76 a & $13.67 \mathrm{a}$ \\
\hline DBAn & $38.54 \mathrm{~b}$ & $29.68 \mathrm{~b}$ & 11.34 & $10.76 \mathrm{a}$ & $21.38 \mathrm{a}$ & $29.03 \mathrm{~b}$ & $14.67 \mathrm{~b}$ \\
\hline DBs & $57.35 \mathrm{a}$ & $35.23 \mathrm{a}$ & 11.21 & $10.13 \mathrm{~b}$ & $14.54 \mathrm{~b}$ & $33.21 \mathrm{a}$ & $16.13 \mathrm{a}$ \\
\hline $\mathrm{P}($ subs $)$ & $<0.0001$ & $<0.0001$ & $<0.001$ & $<0.001$ & $<0.001$ & $<0.01$ & $<0.01$ \\
\hline $\mathrm{P}(\mathrm{An})$ & $<0.001$ & $<0.001$ & 0.35 & $<0.01$ & $<0.01$ & $<0.05$ & $<0.05$ \\
\hline $\mathrm{P}($ subsxAn $)$ & 0.28 & 0.33 & 0.31 & 0.37 & 0.29 & 0.36 & 0.35 \\
\hline SEM & 1.83 & 1.77 & 0.084 & 0.075 & 0.61 & 1.32 & 0.63 \\
\hline
\end{tabular}

Different letters within a column indicate significant differences between treatments with/without An ( $\mathrm{P} \leq 0.05)$.

${ }^{1}$ WSAn: wheat straw with Aspergillus niger (An), WSs: wheat straw without An, BSAn: barley straw with An, BSs: barley straw without An, OHAn: oats hull with An, OHs: oats hull without An, DAAn: dehydrated alfalfa with An, DAs: dehydrated alfalfa without An, DBAn: dehydrated ballica with An, DBs: dehydrated ballica without An.

${ }^{2} \mathrm{NDF}$ : neutral detergent fiber, ADF: acid detergent fiber.

${ }^{3} \mathrm{CP}$ : crude protein, TP: true protein, $\mathrm{SN}$ : $\mathrm{N}$ soluble fraction.

${ }^{4} \mathrm{NDIN}$ : insoluble $\mathrm{N}$ in neutral detergent, ADIN: insoluble $\mathrm{N}$ in acid detergent.

${ }^{5}$ Each value represents incubation assays for three repetitions with duplication.

Table 3. Effect of substrate type and incubation time on in vitro digestion with Aspergillus niger (An) of dry matter, neutral detergent fiber and acid detergent fiber ${ }^{1}$. Experiment 2.

\begin{tabular}{lcccccc}
\hline Treatment & $\begin{array}{c}\text { IVDMD }_{72} \\
\% \mathrm{DM}^{2}\end{array}$ & $\begin{array}{c}\text { IVDMD }_{144} \\
\% \mathrm{DM}\end{array}$ & $\begin{array}{c}\mathrm{DVNDF}_{72} \\
\% \mathrm{NDF}\end{array}$ & $\begin{array}{c}\mathrm{DVNDF}_{144} \\
\% \mathrm{NDF}\end{array}$ & $\begin{array}{c}\mathrm{DVADF}_{72} \\
\% \mathrm{ADF}^{2}\end{array}$ & $\begin{array}{c}\mathrm{DVADF}_{144} \\
\% \mathrm{ADF}^{2}\end{array}$ \\
\hline WSAn & $25.72 \mathrm{c}^{3}$ & $33.12 \mathrm{c}$ & $16.33 \mathrm{c}$ & $27.83 \mathrm{c}$ & $8.74 \mathrm{~b}$ & $13.78 \mathrm{~b}$ \\
BSAn & $26.97 \mathrm{c}$ & $34.41 \mathrm{c}$ & $17.68 \mathrm{c}$ & $29.30 \mathrm{c}$ & $7.95 \mathrm{~b}$ & $13.57 \mathrm{~b}$ \\
OHAn & $20.65 \mathrm{~d}$ & $29.38 \mathrm{~d}$ & $13.45 \mathrm{~d}$ & $25.00 \mathrm{~d}$ & $7.73 \mathrm{~b}$ & $13.56 \mathrm{~b}$ \\
DAAn & $37.78 \mathrm{a}$ & $49.47 \mathrm{a}$ & $24.76 \mathrm{a}$ & $36.76 \mathrm{a}$ & $11.52 \mathrm{a}$ & $16.98 \mathrm{a}$ \\
DBAn & $34.31 \mathrm{~b}$ & $45.51 \mathrm{~b}$ & $21.28 \mathrm{~b}$ & $32.80 \mathrm{~b}$ & $10.33 \mathrm{a}$ & $15.75 \mathrm{a}$ \\
P(subs) & $<0.001$ & $<0.001$ & $<0.001$ & $<0.001$ & $<0.01$ & $<0.01$ \\
P(time) & $<0.01$ & $<0.01$ & $<0.01$ & $<0.01$ & $<0.01$ & $<0.01$ \\
P(subsxtime) & 0.41 & 0.36 & 0.33 & 0.42 & 0.46 & 0.28 \\
SEM & 0.053 & 0.042 & 0.023 & 0.017 & 0.011 & 0.008 \\
\hline
\end{tabular}

Different letters within a column indicate significant differences $(\mathrm{P} \leq 0.05)$.

${ }^{1} \mathrm{IVDMD}_{72}$ : in vitro dry matter digestion at $72 \mathrm{~h}, \mathrm{IVDMD}_{144}$ : in vitro dry matter digestion at $144 \mathrm{~h}, \mathrm{DVNDF}_{72}:$ in vitro neutral detergent fiber digestion at $72 \mathrm{~h}, \mathrm{DVNDF}_{144}$ : in vitro neutral detergent fiber digestion at $144 \mathrm{~h}, \mathrm{DVADF}_{72}$ : in vitro acid detergent fiber digestion at $72{\mathrm{~h}, \mathrm{DVADF}_{144}}$ in vitro acid detergent fiber digestion at $144 \mathrm{~h}$.

${ }^{2}$ WSAn: wheat straw with Aspergillus niger (An), BSAn: barley straw with An, OHAn: oats hull with An, DAAn: dehydrated alfalfa with An, DBAn: dehydrated ballica with An.

${ }^{3}$ Each value represents incubation assays for three repetitions with duplication. 
substrates tested $(\mathrm{P} \leq 0.01)$, showing the influence of the incubation time; there was no interaction between incubation time and substrate type. The highest value for $\mathrm{DVNDF}_{144}(\mathrm{P} \leq 0.05)$ was observed in the DAAn treatment ( $36.76 \% \mathrm{NDF})$, followed by the DBAn treatment (32.8\% NDF). WSAn and BSAn did not differ $(\mathrm{P}>0.05)$ in $\mathrm{DVNDF}_{144}$, with an average of $28.57 \% \mathrm{NDF}$. The lowest value for $\mathrm{DVNDF}_{144}(\mathrm{P} \leq 0.05)$ was observed in the OHAn treatment $(25 \% \mathrm{NDF})$. Moreover, $\mathrm{DVADF}_{72}$ and DVADF $_{144}$ were affected by substrate type ( $\mathrm{P} \leq 0.01$ and $\mathrm{P} \leq 0.01$, respectively). Similarly, incubation time affected the amount of the lignocellulosic fraction digested in all substrates studied $(\mathrm{P} \leq 0.01)$. DAAn and DBAn treatments showed the highest values of $\mathrm{DVADF}_{144}(\mathrm{P} \leq 0.05)$, with no differences between them $(\mathrm{P}>0.05)$; these treatments averaged $16.37 \%$ ADF. The DVADF ${ }_{144}$ of WSAn, BSAn and OHAn treatments were similar $(\mathrm{P}>0.05)$, with an average of $13.64 \%$ ADF. As seen in Table 3, in all substrates and parameters evaluated, the level of digestion was lower at $72 \mathrm{~h}$ of incubation than at $144 \mathrm{~h}$ incubation $(\mathrm{P} \leq 0.05)$. In general, these results suggest that the hydrolytic activity of $A n$ continues after $72 \mathrm{~h}$ incubation, peaking at $144 \mathrm{~h}$.

\section{Discussion}

One of the primary findings of this research is the decrease in NDF and ADF content of the substrates tested, as a result of digestion by $A n$ under in vitro conditions. In effect, the decrease in NDF and ADF content, observed in all substrates studied (Table 2), would allow improved digestive potential, especially for WS, BS and $\mathrm{OH}$ substrates, because these could be included as ingredients in ruminant diets. This is possible due to the decrease in cell wall content, and in particular, the lignocellulosic fractions, which are the most resistant to the enzymatic action of microorganisms in the rumen (Sniffen et al., 1992; Colombatto et al., 2007). However, digestibility is the most appropriate parameter to describe substrate susceptibility to the enzymatic degradation system. Reviewing the levels of digestion (Table 3), it can be seen that degradation was generally higher with the DA and DB substrates (forage). The average value of those substrates was $34.78 \%$ for DVNDF $_{144}$ and $16.37 \%$ for DVADF ${ }_{144}$ compared with WS, BS and $\mathrm{OH}$ substrates, which averaged $27.38 \%$ and $13.64 \%$, respectively. This relationship was clearly associated with IVDMD $_{144}$ values, given the original magnitude of fibrous fractions in the foods assessed (the correlation coefficient ( $\mathrm{r}$ ) between IVDMD I44 and DVNDF $_{144}$ was 0.979; and between IVDMD $_{144}$ and DVADF ${ }_{144}$ was 0.972 , across all substrates). In the case of treatments DAAn and DBAn, IVDMD ${ }_{144}$ values averaged $47.49 \%$, whereas the WSAn, BSAn and OHAn treatments averaged $32.3 \%$, suggesting that the $\mathrm{DM}$ of forage foods was more responsive to $\mathrm{An}$ hydrolytic enzymes (under in vitro conditions), resulting in a greater degree of degradation. This difference could be due to variation in the chemical composition of the substrates. The DA and DB forages had a lower initial level of NDF and ADF relative to $\mathrm{WS}, \mathrm{BS}$ and $\mathrm{OH}$ substrates (Table 1). Most likely, the chemical structures in the WS, BS and $\mathrm{OH}$ cell walls were more lignified, and therefore possessed a more complex integration of lignin in the cellulosic matrix, making it more resistant to fibrolytic enzyme action (Shrivastava et al. 2012). Generally, the complexity of the lignocellulosic matrix and its interaction with proteins increases in more advanced growth stages of the plant. It is noted that WS and BS corresponded to post-harvest waste, and $\mathrm{OH}$ corresponded to a more aged plant biomass, whereas DA and DB came from first cut forage plants with a phenological state prior to flowering. To improve access of fungal enzymes to the organic matter in the substrates, it is necessary to break the lignocellulosic and hemicellulosic structures located in the cell walls (Kuhad et al., 1997; Colombatto et al., 2007); when this occurs, the digestion of substrates is accelerated and higher levels of degradation can be achieved. It should be considered that during the process of enzymatic digestion of organic matter, a diverse pool of polysaccharidases and proteases act synergistically, and can liberate 
nitrogen compounds and carbon skeletons highly resistant to degradation. Indeed, $A n$ has a powerful pool of fibrolytic and proteolytic enzymes (Villas-Boas et al., 2002; Howard et al., 2003; Pensupa et al., 2013), which would explain the levels of degradation of DM and fibrous structures found in this investigation. With respect to incubation time, the results showed differences in the magnitude of $A n$ digestion achieved between $72 \mathrm{~h}$ and $144 \mathrm{~h}$, a phenomenon observed for all substrates and for all parameters measured (Table 3). Although a kinetic study of the degradation of $\mathrm{DM}$ and fibrous fractions was not performed in this study, these results show that digestion had not begun to asymptote at $72 \mathrm{~h}$; that occurred later in incubation. In previous studies, our laboratory found asymptotic values of $A n$ digestion of fibrous substrates with kinetic times approaching 100-120 $\mathrm{h}$. Therefore, in this study, $144 \mathrm{~h}$ was chosen as end of incubation. It should be noted that the average level of digestion at $72 \mathrm{~h}$ of incubation, for all substrates, was $29.09 \% \mathrm{DM}, 18.7 \% \mathrm{NDF}$ and $9.25 \%$ ADF to IVDMD ${ }_{72}, \mathrm{DVNDF}_{72}$ and $\mathrm{DVADF}_{72}$, respectively. These values represent $75.79 \%, 61.64 \%$ and $62.83 \%$, respectively, of the average digestion achieved at $144 \mathrm{~h}$ of incubation (across all substrates). These observations allow us to state that a significant fraction $(>60 \%)$ of the hydrolytic activity of $A n$ took place during the first $72 \mathrm{~h}$. However, $A n$ requires additional incubation time to reach its full digestive potential. Furthermore, the observed increase of SN in all treatments (Table 2) reveals probable proteolytic activity, although it was not directly measured in this investigation. Normally, solubilization of nitrogenous compounds is the result of protein degradation. Moreover, the decrease in NDIN and ADIN content in all treatments $(\mathrm{P} \leq 0.05)$ is directly related to increased $\mathrm{SN}$, indicating possible proteolytic activity of $A n$ during incubation. Additionally, this situation can be connected to the increase in TP content in all treatments, which could be attributed to the increase in $A n$ cell biomass growing on the substrates. Fiber digestion of the substrates tested (NDF and ADF) provided $A n$ with energy and carbon skeletons for cell reproduction and growth, implying, although it was not measured directly, a likely increase in microbial protein synthesis. In this context, it is noted that the largest increases in $\mathrm{TP}(\mathrm{P} \leq 0.05)$, the nutritional parameter that can be directly linked to protein synthesis, were observed in the DAAn and DBAn treatments, which averaged a $0.59 \%$ increase in TP. In comparison, WSAn, BSAn and OHAn treatments averaged a TP increase of $0.32 \%$. A possible explanation for these differences is that forage foods (DA and DB) showed the greatest digestibility of DM, NDF and ADF, which allowed access to more energy, carbonaceous skeletons and nitrogen sources for $A n$ metabolism during incubation. Additionally, there may have been some variability in the efficiency of TP synthesis performed by $A n$, as a result of digesting and metabolizing substrates and nutrients of different chemical nature (Velasquez et al., 2012).

In general, it can be stated that the results of this investigation confirm the fibrolytic potential of $A n$, which could improve the nutritive value of fibrous foods. This would be achieved by digestion of structural carbohydrates, together with release nitrogenous fractions located in cell walls, producing a change in the potential digestibility of treated foods. Additionally, it should be considered that $A n$ cell biomass (growing on these substrates) forms part of the final mass of the bioprocess, providing protein of high biological value, carbohydrates and vitamins (Rajesh et al., 2010), along with other nutrients contained in the fungal protoplasm.

\section{Acknowledgments}

We thank Químico Laborista MSc. María Isabel Martínez for collaboration in the laboratory experiments. This project was funded by DGIP 2009308 of Universidad Católica de Temuco (Chile). 


\title{
Resumen
}

\begin{abstract}
A. Velásquez, P. Marnet y R. Arias. 2015. Mejoramiento de la calidad nutritiva de alimentos fibrosos a través de la digestión in vitro con Aspergillus niger. Cien. Inv. Agr: 42(1): 4555. En un primer ensayo se estudió el efecto de la incubación in vitro con Aspergillus niger (An) y el tipo de sustrato sobre la composición química de alimentos fibrosos. En un segundo ensayo se evaluó el efecto del tipo de sustrato y el tiempo de incubación $(0,72$ y 144 h) sobre la digestión in vitro con An de la materia seca (IVDMD), fibra detergente neutro (DVNDF) y fibra detergente ácida (DVADF). Se evaluaron los sustratos paja de trigo: WS, paja de cebada: BS, cáscara de avena: OH, alfalfa deshidratada: DA y ballica deshidratada: DB. Para ambos experimentos las incubaciones se realizaron en matraces Erlenmeyer de $250 \mathrm{~mL}$; la masa de sustrato a incubar fue de $2 \mathrm{~g}$, adicionados a un medio de cultivo $(\mathrm{pH}=6)$, incubado con sistema de ventilación constante a temperatura de $28{ }^{\circ} \mathrm{C}$. La dosis de $A n$ consistió en $3 \mathrm{~mL}$ frasco ${ }^{-1}$ de una solución de $5,3 \times 10^{6}$ esporas $\mathrm{mL}^{-1}$. El tiempo de incubación para el primer ensayo fue de $144 \mathrm{~h}$. Transcurrido este tiempo, se procedió a homogenizar (Blender) el contenido total de los matraces por un minuto. Posteriormente, se realizó un análisis bromatológico a la masa total incubada, sin separar la biomasa de $A n$. No se observó efecto de la interacción en ninguna de las variables estudiadas. La incubación con $A n$ mostró un efecto sobre el contenido de paredes celulares (FDN) y las fracciones lignocelulósicas (FDA). Se observó un incremento en la Proteína Verdadera (TP) y en el Nitrógeno Soluble (SN) en todos los sustratos evaluados, y su respuesta fue diferente según el tipo de sustrato. Los mayores incrementos en TP se observaron en los sustratos DA y DB (0,55 y 0,63\% DM, respectivamente). IVDMD, DVNDF y DVADF se vieron afectadas por el tipo de sustrato y el tiempo de incubación. El valor más alto de IVDMD $_{144}$ se observó en el tratamiento DAAn (49,47\% DM), seguido de DBAn, con un valor de 45,51\% DM. OHAn mostró el valor más bajo de $\operatorname{IVDMD}_{144}(29,38 \% \mathrm{DM})$. Los resultados permitieron inferir que $A n$ posee el potencial fibrolítico y metabólico para mejorar el valor nutritivo de alimentos fibrosos, a través de la digestión de los carbohidratos estructurales y liberación de fracciones nitrogenadas incrustadas en las paredes celulares, implicando un cambio en la composición química y en la digestibilidad potencial de los alimentos tratados.
\end{abstract}

Palabras clave: Aspergillus niger, calidad nutricional, digestión in vitro, sustratos fibrosos.

\section{References}

AOAC-Association of Official Analytical Chemists 1990. Official Methods of Analysis. 15 th Edition. Washington DC, USA.

Arora, D.S., R.K. Sharma, and P. Chandra. 2011. Biodelignification of wheat straw and its effect on in vitro digestibility and antioxidant properties. Int. Biodeterior. Biodegrad. 65:352-358.

Basu, S., R. Gaur, J. Gomes, T.R. Sreekrishnan, and V.S. Bisaria. 2002. Effect of seed culture on solid state bioconversion of wheat straw by Phanerochaete chrysosporium for animal feed production. J. Biosci. Bioeng. 1:25-30.

Colombatto, D., F.L. Mould, M.K. Bhat, and E. Owen. 2007. Influence of exogenous fibrolytic enzyme level and incubation $\mathrm{pH}$ on the in vitro ruminal fermentation of alfalfa stems. Anim. Feed Sci.Tech. 137:150-162.

Gaitán-Hernández, R., M. Esqueda, A. Gutiérrez, and M. Beltrán-García. 2011. Quantitative changes in the biochemical composition of lignocellulosic residues during the vegetative growth of Lentinula edodes. Braz. J. Microbiol. 42:30-40.

Hernández-Díaz, R., D.J. Pimentel-González, A.C. Figueira, G. Viniegra-González, and R.G. Campos-Montiel. 2010. Influence of an aerobic fungus grown on solid culture on ruminal degradability and on a mixture culture of anaerobic cellulolytic bacteria. J Anim. Physiol. Anim. Nutr. 94:330-337. 
Howard, R.L., E. Abotsi, E.L. Jansen van Rensburg, and S. Howard. 2003. Lignocellulose biotechnology: issues of bioconversion and enzyme production. Afr. J. Biotechnol. 2:602-19.

Jones, J. 1994. Fungal adhesion. Mycological Research 98: 961- 981.

Kang, S.W., Y.S. Park, J.S. Lee, S.I. Hong, and S.W. Kim. 2004. Production of cellulases and hemicellulases by Aspergillus niger KK2 from lignocellulosic biomass. Bioresource Technology 91:153-156.

Kuhad, R.C., A. Singh, and K. Ericsson. 1997. Microorganisms and enzymes involved in the degradation of plant fiber cell walls. Adv. Biochem. Eng. Biotechnol. 57:45-125.

Leonowicz, A., A. Matuszewska, J. Luterek, D. Ziegenhagen, M. Wojtas-Wasilewska, N.S. Cho, M. Hofrichter, and J. Rogalski. 1999. Biodegradation of lignin by white-rot fungi. Funct. Gen. Biol. 27:175-185.

Liu, J.X., E.R. Orskov, and X.B. Chen. 1999. Optimization of steam treatment as a method for upgrading rice straw as feeds. Anim. Feed Sci. Technol. 76:345-357.

Nagarajan, S. 2005. Can India produce enough wheat even by 2020? Curr. Sci. 89:1467-1471.

Park, Y.S., S.W. Kang, J.S. Lee, S.I. Hong, and S.W. Kim. 2002. Xylanase production in solid state fermentation by Aspergillus niger mutant using statistical experimental designs. Appl. Microbiol. Biotechnol. 58:761-766.

Pensupa, N., M. Jin, M. Kokolski, D. Archer, and C. Du. 2013. A solid state fungal fermentationbased strategy for the hydrolysis of wheat Straw. Bioresource Technology 149:261-267.

Rajesh, N., I. Joseph, and R.P. Raj. 2010. Value addition of vegetable wastes by solid-state fermentation using Aspergillus niger for use in aquafeed industry. Waste Management 30:2223-2227.

Robinson, T., and P. Nigam. 2003. Bioreactor design for protein enrichment of agricultural residues by solid state fermentation. Biochemical Engineering Journal 13:197-203.

Rodrigues, M., P. Pinto, R.M. Bezerra, A.A. Dias, C.V. Guedes, V.M. Cardoso, J.W. Cone, L.M. Ferreira, J. Colaco, and C.A. Sequeira. 2008. Ef- fect of enzyme extracts isolated from white-rot fungi on chemical composition and in vitro digestibility of wheat straw. Anim. Feed Sci. Technol. 141:326-338.

Sahoo, B., M.L. Saraswat, N. Haque, and M.Y. Khan. 2002. Influence of chemical treatment of wheat straw on carbon-nitrogen and energy balance in sheep. Small Ruminant Research 44:201-206.

Sánchez, C. 2009. Lignocellulosic residues: Biodegradation and bioconversion by fungi. Biotechnology Advances 27:185-194.

Sarkar, N., S.K. Ghosh, S. Bannerjee, and K. Aikat. 2012. Bioethanol production from agricultural wastes: an overview. Renew. Energy 37: 19-27. In: Pensupa, N., M. Jin, M. Kokolski, D. Archer, and C. Du. 2013. A solid state fungal fermentation-based strategy for the hydrolysis of wheat Straw. Bioresource Technology 149:261-267.

Shrivastava, B., P. Nandal, A. Sharma, K.K. Jain, Y.P. Khasa, T.K. Das, V. Mani, N.J. Kewalramani, S.S. Kundu, and R.C. Kuhad. 2012. Solid state bioconversion of wheat straw into digestible and nutritive ruminant feed by Ganoderma sp. rckk02. Bioresource Technology 107:347-351.

Sniffen, C.J., J.D. O'Connor, P.J. Van Soest, D.G. Fox, and J.B. Russell. 1992. A net carbohydrate and protein system for evaluating cattle diets: II. Carbohydrate and protein availability. J. Anim. Sci. 70: 3562-3577.

Tuyen, V.D., J.W. Cone, J.J. Baars, A.S. Sonnenberg, and W.H. Hendriks. 2012. Fungal strain and incubation period affect chemical composition and nutrient availability of wheat straw for rumen fermentation. Bioresource Technology 111: 336-342.

Van Soest, P.J., J.B. Robertson, and B.A. Lewis. 1991. Methods for dietary fiber, neutral detergent fiber, and nonstarch polysaccharides in relation to animal nutrition. J. Dairy Sci. 74: 3583-3597.

Velásquez, A., R. Arias, and M. Toneatti. 2012. Effect of the type of substrate on the chemical composition and productivity of a protein concentrate of yeast origin. Cien. Inv. Agr. 39:425-434.

Velásquez, A., and R. Arias. 2013. Effect of substrate on the in vitro protein digestibility of extracts generated by Saccharomyces cerevisiae. Cien. Inv. Agr. 40:503-511. 
Villas-Boas, S.G., E. Esposito, and D.A. Mitchell. 2002. Microbial conversion of lignocellulosic residues for production of animal feeds. Animal Feed Science and Technology 98:1-12.
Zafar, S.I., N. Abdullah, M. Iqbal, and Q. Sheeraz. 1996. Influence of nutrient amendment on the biodegradation of wheat straw during solid state fermentation with Trametes versicolor. Int. Biodeterior. Biodegrad. 38:83-87. 
